IVANA JEVREMOVIĆ ${ }^{1}$, MARC SINGER ${ }^{2}$, MOHSEN ACHOUR ${ }^{3}$, SRĐAN NEŠIĆ ${ }^{2}$, VESNA MIŠKOVIĆSTANKOVIĆ ${ }^{1 *}$

${ }^{1}$ University of Belgrade, Faculty of Technology and Metallurgy, Belgrade, Serbia, ${ }^{2}$ Institute for Corrosion and Multiphase Technology, Ohio University, $\mathrm{OH}, \mathrm{USA} .{ }^{3}$ ConocoPhillips Company, Bartlesville, OK, USA
Review paper

ISSN 0351-9465, E-ISSN 2466-2585

UDC: $620.193 .4: 66.021 .2$

doi:10.5937/ZasMat1602195J

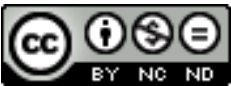

Zastita Materijala 57 (2)

$195-204(2016)$

\title{
Development of an effective method for internal pipeline corrosion control in the presence of $\mathrm{CO}_{2}$
}

\begin{abstract}
This paper reports on progress in developing an effective method for internal pipeline corrosion control in the presence of $\mathrm{CO}_{2}$. The inhibition effect of talloil diethylenetriamine imidazoline (TOFA/DETA imidazoline) on corrosion of mild steel API X65 in $\mathrm{CO}_{2}$-saturated $3 \mathrm{wt}$. \% $\mathrm{NaCl}$ solution was investigated by: linear polarization resistance (LPR), potentiodynamic sweep (PDS), electrical resistance (ER) measurements, and atomic force microscopy (AFM). Novel top-of-theline corrosion (TLC) mitigation method was verified in an innovative glass cell set-up and in a large scale flow loop. It was demonstrated that TOFA/DETA imidazoline can successfully protect the mild steel surface from corrosion in CO2-saturated $3 \mathrm{wt}$. \% $\mathrm{NaCl}$ with the inhibition efficiency up to $92 \%$. The TLC rate of mild steel, as measured in the vapor phase using the ER probe, was reduced effectively by periodic treatment by the foam containing TOFA/DETA imidazoline corrosion inhibitor in both glass cell and the large scale flow loop. The corrosion inhibition efficiency was calculated to be higher than $90 \%$ and the inhibition effect lasted up to $50 \mathrm{~h}$.
\end{abstract}

Keywords: Mild steel; Carbon dioxide corrosion; Corrosion inhibitors, LPR; PDS; AFM; Flow loop.

\section{INTRODUCTION}

Carbon steel is the most commonly used material for construction of pipelines and associated production equipment. Aqueous $\mathrm{CO}_{2}$ corrosion of mild steel presents a significant problem for the oil and gas industry. When dissolved in water, $\mathrm{CO}_{2}$ is hydrated to form carbonic acid which presence leads to a much higher corrosion rate of carbon steel than would be found in a solution of a strong acid at the same $\mathrm{pH}$ [1-6]. Carbon dioxide top-of-the-line corrosion (TLC) occurs in stratified or stratified-wavy flow regimes where a significant temperature gradient between the outside environment and the inner pipeline surface leads to high condensation rates. A thin film of condensed water forms on the sides and on the upper section of the internal pipe walls, and the presence of various corrosive species such as $\mathrm{CO}_{2}$ and acetic acid causes a severe corrosion problem [5-10].

Corresponding author. Vesna Mišković-Stanković

E-mail: vesna@tmf.bg.ac.rs

Paper received: 13.02.2016.

Paper accepted: 17.03.2016.

Paper is available on the website:

www.idk.org.rs/journal
The use of corrosion inhibitors is one of the most practical and cost effective methods for combating $\mathrm{CO}_{2}$ corrosion in oil and gas wells and flowlines [11]. Corrosion inhibitors contain different functional groups, usually polar head (fatty acids, amines, imidazolines, oxygen, sulphur or phosphorus containing species, quaternary amines) and long hydrocarbon chain (typically $\mathrm{C} 14-\mathrm{C} 18$ ), which promote the binding of inhibitor molecules to the metal surface [12-17]. Imidazoline based corrosion inhibitors are cationic surface active compounds widely used for protecting pipelines from $\mathrm{CO}_{2}$ corrosion in the oil and gas industry [18-21].

Conventional mitigation methods can fall short in protecting the top of the line since the conditions do not allow the inhibitor to reach the top sections of the wall [17]. A novel idea consists of injecting the corrosion inhibitor within a foam matrix and delivering the corrosion inhibitor to locations where condensation occurs. This method was designed to uniformly deliver the inhibitor to the inner pipe wall. It should consequently lead to formation of strong chemical bonds that would allow the inhibitor to remain on the pipe wall for long periods of time between treatments. This method could be theoretically implemented without affecting the production conditions within a given pipeline. 
The experimental study performed here includes:

- Investigation of corrosion inhibitor, TOFA/ DETA imidazoline, efficiency on mild steel in $\mathrm{CO}_{2}$-saturated 3 wt. \% NaCl.

- Validation of the novel TLC mitigation method in an innovative glass cell setup.

- Testing of the novel TLC mitigation method in a large scale flow loop under simulated field conditions.

Molecular structure of TOFA/DETA imidazoline is depicted in Fig. 1, where can be seen that inhibitor molecule consists of three different substructures: a nitrogen-containing five member ring, a pendant side chain with a hydrophilic active functional group (ethylamino pendent group) attached to N1 and a long C-17 hydrophobic chain attached to the $\mathrm{C} 2$ atom.

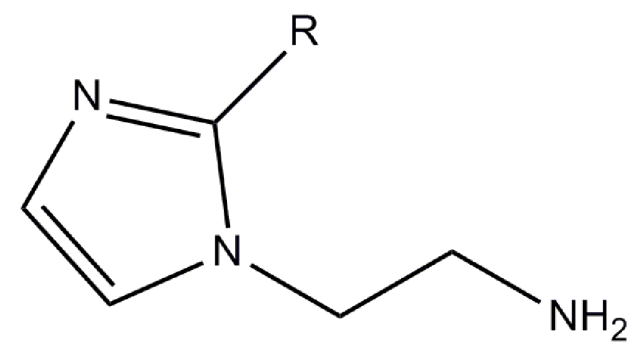

Figure 1 - Molecular structure of TOFA/DETA imidazoline

\section{EXPERIMENTAL}

\subsection{Materials}

X65 carbon steel was used for the corrosion measurements. Its composition (mass \% balance is $\mathrm{Fe}$ ) is $0.13 \mathrm{C}, 0.26 \mathrm{Si}, 1.15 \mathrm{Mn}, 0.32 \mathrm{Al}, 0.16 \mathrm{Mo}$, $0.36 \mathrm{Ni}, 0.131 \mathrm{Cu},<0.009 \mathrm{~S},<0.009 \mathrm{P}$. TOFA/DETA imidazoline is a water dispersible corrosion inhibitor with molecular weight of $359 \mathrm{~g} \mathrm{~mol}^{-1}$, while its density and viscosity measured at $25^{\circ} \mathrm{C}$ are $980 \mathrm{~kg}$ $\mathrm{m}^{-3}$ and $200 \mathrm{mPa} \mathrm{s}$ respectively. Sodium $\mathrm{C} 14-16$ olefin sulfonate synthetic detergent is a high foaming anionic surfactant with a molecular weight of $324 \mathrm{gmol}^{-1}$, water soluble, commercially available as 40 vol. \% aqueous solution with density and viscosity measured at $25^{\circ} \mathrm{C}$ of 880 $\mathrm{kgm}^{-3}$ and $500 \mathrm{mPa}$ s respectively. It consists of a mixture of long chain sulfonate salts prepared by sulfonation of C14-16 alpha olefins.

\subsection{Inhibitor efficiency in the liquid phase}

Experiments were conducted using a conventional three-electrode cell assembly. The rotating cylinder test specimens $\left(5.4 \mathrm{~cm}^{2}\right.$ exposed area), machined from X65 pipeline steel, were used as the working electrode. A platinum mesh was used as the counter electrode and a saturated silver/silver chloride $(\mathrm{Ag} / \mathrm{AgCl})$ reference electrode was connected externally via a Luggin capillary tube. The test specimens were grinded sequentially using 240,320, 400, and 600 grit silicon carbide paper degreased with isopropanol in an ultrasonic water bath and dried with hot air. Experiments were conducted under stagnant conditions at atmospheric pressure, at different temperatures in the range from $20^{\circ} \mathrm{C}$ to $70^{\circ} \mathrm{C}$. Test solution was 3 wt. \% $\mathrm{NaCl}$. The solutions were deoxygenated by purging $\mathrm{CO}_{2}$ gas for $1 \mathrm{~h}$ before the start of the experiment. TOFA/DETA imidazoline was introduced into the solution in the concentration range close to its critical micelle concentration (CMC) from $50 \mathrm{ppm}_{\mathrm{v}}$ to $90 \mathrm{ppm}_{\mathrm{v}}$. TOFA/DETA imidazoline has been found to have $\mathrm{CMC}$ value of $65 \mathrm{ppm}_{\mathrm{v}}$ in 3 wt. \% aqueous $\mathrm{NaCl}$ solution saturated with $\mathrm{CO}_{2}$ at $20^{\circ} \mathrm{C}, \mathrm{pH} 5$ [19]. All the electrochemical measurements were carried out using a reference Reference 600TM Potentiostat/ Galvanostat/ZRA (Gamry Instruments, Inc., Warminister, PA, USA). PDS measurements were carried out subsequently after $30 \mathrm{~min}$ of opencircuit potential, $E_{\text {ocp }}$, measurements.

The Potentiodynamic polarization measurements (PDS) were carried out from a cathodic potential of $-0.25 \mathrm{~V}$ to an anodic potential of $0.25 \mathrm{~V}$ with respect to the corrosion potential, at a scan rate of $1 \mathrm{mV} \mathrm{s}^{-1}$. The linear polarization resistance (LPR) measurements were carried out from a cathodic potential of $-5 \mathrm{mV}$ to an anodic potential of $5 \mathrm{mV}$ with respect to the corrosion potential at a scan rate of $0.125 \mathrm{mV} \mathrm{s}^{-1}$. The analysis of the morphology of the mild steel surface was carried out using atomic force microscopy (AFM), operated in the contact mode under ambient conditions, at a scan rate $0.7 \mathrm{~Hz}$, scan angle 0 , scan points 256 and scan lines 256 using an MFP-3d Standing Alone AFM instrument, Asylum Research, Inc. Images of the specimens were recorded after $24 \mathrm{~h}$ exposure time in 3 wt. \% NaCl purged with $\mathrm{CO}_{2}$ gas at $20^{\circ} \mathrm{C}$, and at $70^{\circ} \mathrm{C}$ without and with $70 \mathrm{ppm}_{\mathrm{v}}$ of TOFA/DETA imidazoline. The purpose of investigating the topography of the surface was to characterize the surface roughness on a microscale.

\subsection{Corrosion Inhibitor performance in the vapor phase - glass cell}

The objective here was to prove if the corrosion inhibitor can be carried by the foam matrix and provide sufficient corrosion inhibition on the top of the line. To achieve this goal, two glass cells were used as shown in Fig. 2. 

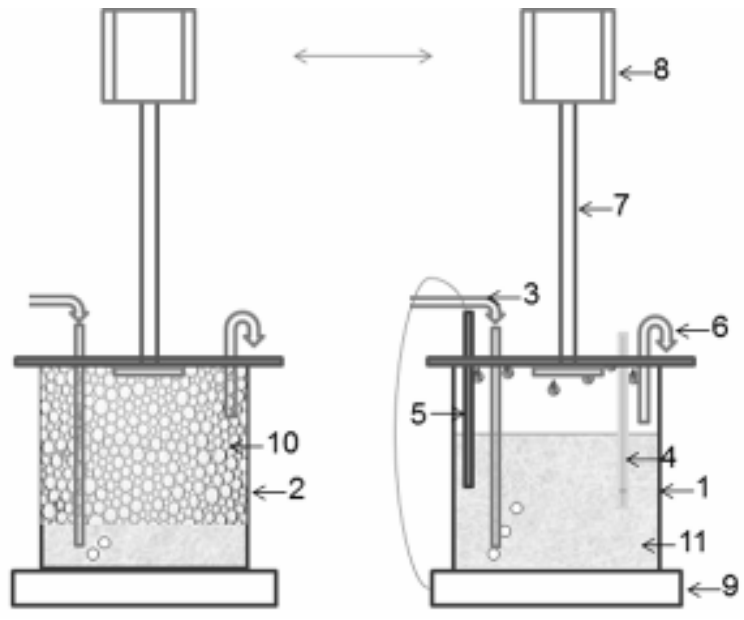

Figure 2 - The glass cell setup which consists of a foaming cell and a corrosion cell (1-corrosion cell, 2 -foaming cell, 3-bubbler, 4-pH probe, 5temperature probe, 6-gas outlet, 7-ER probe, 8-ER transmitter, 9-hot plate, 10-foam, 11-liquid).

The "corrosion cell" contained 3 wt. \% $\mathrm{NaCl}$ solution with acetic acid in a concentration of 0.02 mol dm${ }^{-3}$ while the "foaming cell" contained 20 vol. $\%$ aqueous foaming agent (sodium C14-16 olefin sulfonate) with $1000 \mathrm{ppm}_{\mathrm{v}}$ of TOFA/DETA imidazoline added. The solution temperature was increased to $70^{\circ} \mathrm{C}$ and the $\mathrm{pH}$ was adjusted to $\mathrm{pH}$ 4. When the desired conditions were achieved, the ER probe was installed flush-mounted at the bottom of a stainless steel lid of the corrosion cell. Cooling of the probe was maintained by using a heat exchanger, so the ER probe was exposed to water condensation. To limit water vapor loss during the test, a reflux condenser was used in the exhaust line. Once the non-inhibited baseline corrosion rate was obtained in the corrosion cell, the foam matrix was created by immersing the $\mathrm{CO}_{2}$ gas bubbler into the solution of the foaming cell. When a plug of foam of good consistency was formed there, the ER probe was taken out from the corrosion cell and flush-mounted onto the lid of the foaming cell where it was contacted by the foam for a set amount of time. It was then returned back to the corrosion cell. In this way, intermittent foam contact with the top of the line was simulated.

\subsection{Corrosion Inhibitor performance in the vapor phase - flow loop}

All experiments have been performed in a wet gas corrosion flow loop, specially designed to study the effect of operating parameters on the corrosion of carbon steel under condensing conditions. The large scale flow loop is described elsewhere in detail [22]. The experimental conditions are summarized in Table 1.
Table 1 - Experimental conditions in the flow loop

\begin{tabular}{|c|c|}
\hline Parameters & Conditions \\
\hline Test solution & $\begin{array}{c}0.02 \mathrm{~mol} \mathrm{dm}^{-3} \mathrm{HAc} \text { in DI } \\
\text { water }\end{array}$ \\
\hline Corrosion inhibitor & TOFA/DETA imidazoline \\
\hline $\begin{array}{l}\text { Inhibitor concentration, } \\
\mathrm{ppm}_{\mathrm{v}}\end{array}$ & $0 ; 10000$ \\
\hline Foaming agent & $\begin{array}{l}\text { sodium C14-16 olefin } \\
\text { sulfonate }\end{array}$ \\
\hline $\begin{array}{l}\text { Foaming agent } \\
\text { concentration }\end{array}$ & 10 vol. $\%$ \\
\hline $\begin{array}{l}\text { Pressure in the } \\
\text { system, bar }\end{array}$ & 1.1 \\
\hline $\begin{array}{l}\text { Superficial gas } \\
\text { velocity, } \mathrm{ms}^{-1}\end{array}$ & 0.5 to 5 \\
\hline $\begin{array}{l}\text { Superficial liquid } \\
\text { velocity, } \mathrm{ms}^{-1}\end{array}$ & $<0.01$ \\
\hline
\end{tabular}

The corrosion rate data were acquired using ER measurements. The ER probes were introduced into the flow loop as soon as the system had reached steady state (temperature, pressure, and flow velocities). The sensing elements of the ER probes were pretreated with 78 wt. $\% \mathrm{H}_{2} \mathrm{SO}_{4}$ for $30 \mathrm{~s}$, rinsed with DI water for $10 \mathrm{~s}$, polished with emery paper grit 600 , and rinsed with DI water again. The ER probe was then flush mounted on the top pipe wall of the flow loop test section so that the sensing element was directly exposed to the corrosive environment. The exposure time was between $30 \mathrm{~h}$ and $60 \mathrm{~h}$.

\section{RESULTS AND DISCUSSIONS}

\subsection{Inhibitor efficiency in the liquid phase}

\subsubsection{PDS measurements}

Potentiodynamic polarization curves recorded for mild steel in $\mathrm{CO}_{2}$-saturated $3 \mathrm{wt}$. $\% \mathrm{NaCl}$ solution without and with varying concentrations of TOFA/DETA imidazoline at different temperatures in the range from $20^{\circ} \mathrm{C}$ to $50^{\circ} \mathrm{C}$ are shown in Fig. 3 .

It is widely accepted that the mechanism of mild steel corrosion in $\mathrm{CO}_{2}$-saturated $3 \mathrm{wt}$. $\% \mathrm{NaCl}$ is under both mass transfer and activation control [24]. The cathodic limiting current is commonly attributed to the superposition of the diffusion limited reduction of $\mathrm{H}^{+}$and $\mathrm{H}_{2} \mathrm{CO}_{3}$. It was reported that at $\mathrm{pH} 5$, the dominant cathodic reaction is $\mathrm{H}_{2} \mathrm{CO}_{3}$ reduction while the contribution of $\mathrm{H}^{+}$was much smaller than at lower $\mathrm{pH}$. The slow replenishment of the $\mathrm{H}_{2} \mathrm{CO}_{3}$ and consequently the limiting current for this reaction is controlled by the slow hydration of dissolved $\mathrm{CO}_{2}$ [25]. 

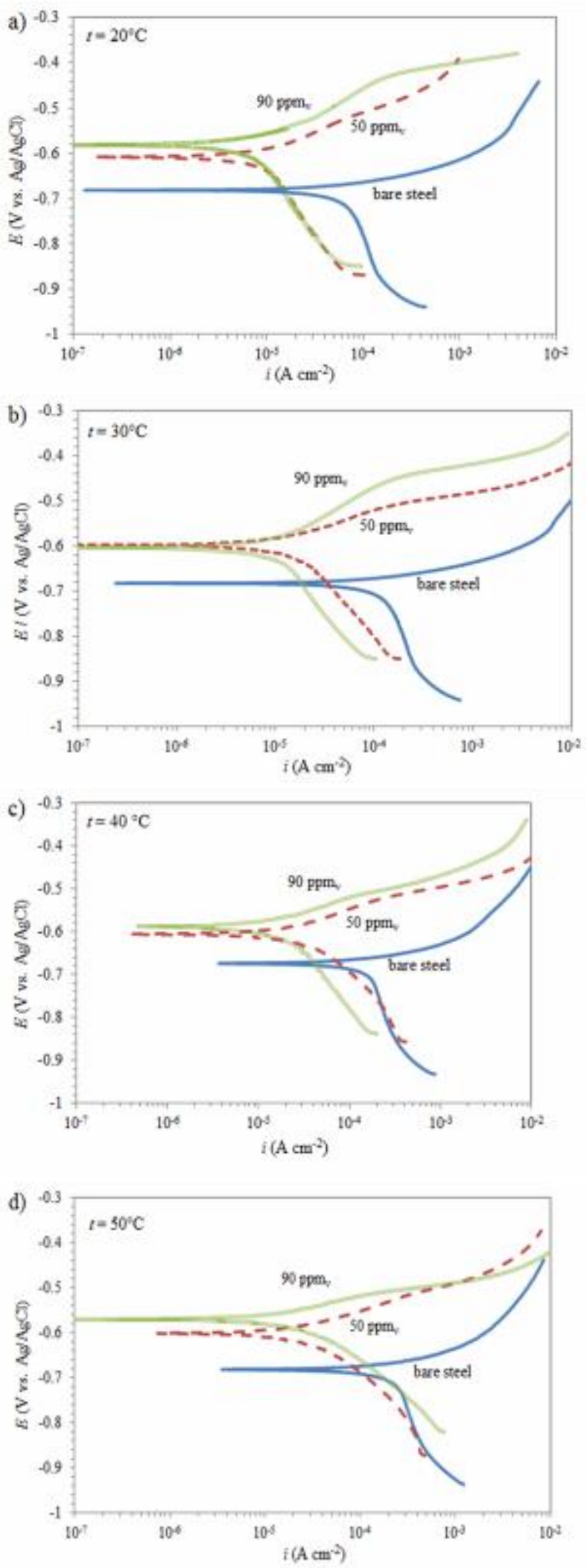

Figure 3 - Polarization curves of mild steel in 3 wt. $\% \mathrm{NaCl}$ solution with varying concentrations of TOFA/DETA imidazoline at: a) $20^{\circ} \mathrm{C}$, b) $30^{\circ} \mathrm{C}$, c) $40^{\circ} \mathrm{C}$ and d) $50^{\circ} \mathrm{C}$. (Reprinted with permission from [23] Copyright 2015 John Wiley and Sons).
The change of slope of the cathodic curve at high overpotentials corresponds to direct $\mathrm{H}_{2} \mathrm{O}$ reduction. It is reported that the anodic dissolution of iron is affected by the presence of $\mathrm{CO}_{2}$, where carbonic species in solution are acting as a chemical ligands and catalyzing the dissolution of iron [8]. The addition of TOFA/DETA imidazoline shifts the corrosion potential to more positive values and decreases the corrosion current density of mild steel. It can be concluded that TOFA/DETA imidazoline inhibits the corrosion of mild steel to an appreciable extent and the extent of inhibition is dependent on the inhibitor concentration. It can be also noticed that the current density increased with increasing temperature in the presence and absence of corrosion inhibitor due to the acceleration of all the processes involved in corrosion. According to Fig. 3, the presence of TOFA/DETA imidazoline affects both anodic and cathodic partial reaction with a more noticeable anodic effect. Consequently TOFA/DETA imidazoline can be considered a mixed-type inhibitor, with the predominant influence on the anode process due to the adsorption of the inhibitor molecules on the corresponding active sites. The corrosion current density was determined graphically by the intersection of the extrapolated Tafel region of the anodic and the cathodic polarization curves. Values of kinetic parameters deduced from the polarization curves including anodic and cathodic Tafel constants, $b_{\mathrm{a}}$ and $b_{\mathrm{c}}$, corrosion potential, $E_{\text {corr }}$, corrosion current density, $j_{\text {corr }}$, corrosion rate, $v_{\text {corr }}$, and inhibition efficiency, $\eta$ $(\%)$, are listed in Table 2. Corrosion rate, $v_{\text {corr }}$, and $\eta(\%)$ were calculated using the following equations, respectively:

$$
\begin{aligned}
& v_{\text {corr }}=\frac{M}{n F \rho} j_{\text {corr }} \\
& \eta(\%)=\frac{j_{\text {corr }}^{0}-j_{\text {corr }}}{j_{\text {corr }}^{0}} \times 100
\end{aligned}
$$

where $\mathrm{M}$ is molar mass of $\mathrm{Fe}\left(55.845 \mathrm{~g} \mathrm{~mol}^{-1}\right), \rho$ is the density $\left(7.874 \mathrm{~g} \mathrm{~cm}^{-3}\right), \mathrm{n}$ is the charge number which indicates the number of electrons exchanged in the dissolution reaction, $F$ is the Faraday constant, (96485 C mol ${ }^{-1}$ ), $j$ corr and $j_{\text {corr }}$ are corrosion current densities of mild steel in $3 \mathrm{wt}$ \% $\mathrm{NaCl}$ solution without and with TOFA/DETA imidazoline, respectively, determined by extrapolation of Tafel lines to $E_{\text {corr }}$.

By assessing Table 2 data, a significant decrease in $j_{\text {corr }}$ and consequently $v_{\text {corr }}$ with the increasing concentrations of TOFA/DETA imidazoline is evident, leading to the increase of inhibition efficiency up to $92 \%$. The shift of $E_{\text {corr }}$ value to more noble values indicates that the 
inhibitor can effectively inhibit the anodic dissolution of mild steel in $\mathrm{CO}_{2}$-saturated chloride solution. However, $j_{\text {corr }}$ increased with increasing temperature due to corrosion process acceleration with increasing temperature, while the temperature had no significant effect on the inhibitor efficiency. In $\mathrm{CO}_{2}$ corrosion the determination of Tafel slopes is not straightforward due to the complexity of the polarization curves. As can be seen in Table 2 almost infinite value of $b_{\mathrm{c}}$ and the value of $b_{\mathrm{a}}$ close to $40 \mathrm{mV} \mathrm{dec}^{-1}$ were observed for bare steel in 3 wt. $\% \mathrm{NaCl}$ saturated with $\mathrm{CO}_{2}$, at all given temperatures. This is consistent with $b_{\mathrm{a}}$ values (40$60 \mathrm{mV} \mathrm{dec}^{-1}$ ) typically reported for iron dissolution controlled by charge transfer [26]. It can be observed that both cathodic and anodic Tafel constants increased with TOFA/DETA imidazoline concentration.

Table 2 - Electrochemical data obtained from the potentiodynamic curves at different temperatures carried out on carbon steel in 3 wt. $\% \mathrm{NaCl}$ solution saturated with $\mathrm{CO}_{2}$ with varying concentrations of TOFA/DETA imidazoline. (Reprinted with permission from [23] Copyright 2015 John Wiley and Sons).

\begin{tabular}{|c|c|c|c|c|c|c|c|}
\hline \multirow{2}{*}{$t\left({ }^{\circ} \mathrm{C}\right)$} & $c\left(\mathrm{ppm}_{\mathrm{v}}\right)$ & $\begin{array}{c}b_{\mathrm{a}} \\
\left(\mathrm{mV} \mathrm{dec}^{-1}\right)\end{array}$ & $\begin{array}{c}-b_{\mathrm{c}} \\
\left(\mathrm{mV} \mathrm{dec}^{-1}\right)\end{array}$ & $\begin{array}{c}j_{\text {corr }} \\
\left(10^{4} \mathrm{~A} \mathrm{~cm}^{-2}\right)\end{array}$ & $\begin{array}{c}E_{\text {corr }} \\
(\mathrm{mV} \mathrm{vs.} \mathrm{Ag/AgCl})\end{array}$ & $\theta$ & $\eta(\%)$ \\
\hline \multirow{3}{*}{20} & - & 39 & 590 & 0.64 & -679 & - & - \\
\cline { 2 - 9 } & 50 & 80 & 306 & 0.084 & -608 & 0.87 & 87 \\
\cline { 2 - 9 } & 90 & 110 & 280 & 0.066 & -582 & 0.90 & 90 \\
\hline \multirow{3}{*}{30} & - & 40 & 443 & 1.10 & -683 & - & - \\
\cline { 2 - 9 } & 50 & 70 & 250 & 0.146 & -603 & 0.87 & 87 \\
\cline { 2 - 9 } & 90 & 114 & 278 & 0.087 & -602 & 0.92 & 92 \\
\hline \multirow{3}{*}{40} & - & 40 & 454 & 1.47 & -674 & - & - \\
\cline { 2 - 9 } & 50 & 68 & 190 & 0.250 & -606 & 0.83 & 83 \\
\hline \multirow{3}{*}{50} & 90 & 64 & 273 & 0.140 & -587 & 0.90 & 90 \\
\cline { 2 - 9 } & - & 30 & 490 & 2.10 & -681 & - & - \\
\cline { 2 - 9 } & 90 & 60 & 174 & 0.245 & -601 & 0.89 & 89 \\
\hline
\end{tabular}

\subsubsection{LPR measurements}

LPR was used to continuously measure corrosion rate and follow the inhibitor film formation (Fig. 4). For narrow range of overpotentials relative to $E_{\text {corr }}( \pm 20 \mathrm{mV})$, the relationship between the polarization resistance $R_{\mathrm{ct}}$ and corrosion rate $v_{\text {corr }}$ can be estimated using the Stern and Geary equation:

$$
j_{c o r r}=\frac{b_{a} b_{c}}{2.303\left(b_{a}+b_{c}\right)} \frac{1}{R_{c t}}
$$

Tafel constants were previously determined from the potentiodynamic curves, while the $v_{\text {corr }}$ was calculated using the Faraday law (Eq.1).

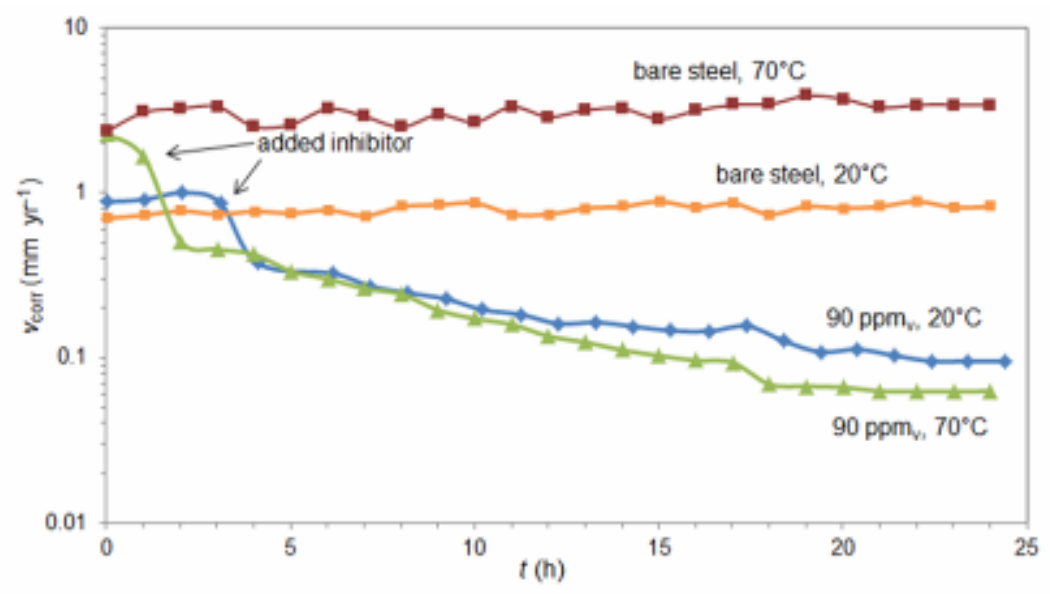

Figure 4 - Polarization curves of mild steel in 3 wt. \% $\mathrm{NaCl}$ at room temperature and at $70^{\circ} \mathrm{C}, \mathrm{pH} 5$, without and with $90 \mathrm{ppm}_{\mathrm{v}}$ TOFA/DETA imidazoline 
It was found that the corrosion rate of mild steel in 3 wt. $\% \mathrm{NaCl}, \mathrm{pH} 5$, at room temperature

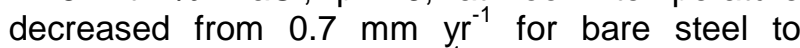
approximately $0.1 \mathrm{~mm} \mathrm{yr}^{-1}$ when $90 \mathrm{ppm}_{\mathrm{v}}$ of TOFA/DETA imidazoline was added. The corrosion rate also decreased from $2.5 \mathrm{~mm} \mathrm{yr}^{-1}$ for bare steel to less than $0.1 \mathrm{~mm} \mathrm{yr}^{-1}$ by adding $90 \mathrm{ppm}_{\mathrm{v}}$ of TOFA/DETA imidazoline at $70^{\circ} \mathrm{C}$. Results obtained from LPR measurements are in good agreement with that obtained from PDS measurements. It can be assumed that the imidazoline ring and nitrogen heteroatom are the active sites of TOFA/DETA imidazoline corrosion inhibitor while the hydrocarbon chain forms hydrophobic film and protect the metal surface from corrosive species. It was also demonstrated that TOFA/DETA imidazoline protects the steel surface against corrosion by forming self-assembled films [19].

\subsubsection{Surface morphology}

Further investigation of the corrosion resistance ability of TOFA/DETA imidazoline films was carried out by means of atomic force microscopy (AFM) in order to characterize the mild steel surface microstructure. The three-dimensional AFM images of mild steel surface after $24 \mathrm{~h}$ of exposure to $3 \mathrm{wt}$. $\% \mathrm{NaCl}$ solutions without and with TOFA/DETA imidazoline at $20^{\circ} \mathrm{C}$ and at $70^{\circ} \mathrm{C}$ are shown in Fig. 5.

In the absence of inhibitor (Fig. 5a and b), the mild steel surface was strongly damaged due to metal dissolution in the corrosive solution. Nevertheless, the appearance of steel surface was significantly different after the introduction of TOFA/DETA imidazoline to the corrosive solution. The Fig. $5 \mathrm{c}$ and $\mathrm{d}$ clearly show that the corrosion rate of mild steel decreased and very flat surface appeared, suggesting that TOFA/DETA imidazoline forms an inhibitive film on the mild steel surface.These results support the results of the electrochemical measurements, discussed above.

a)

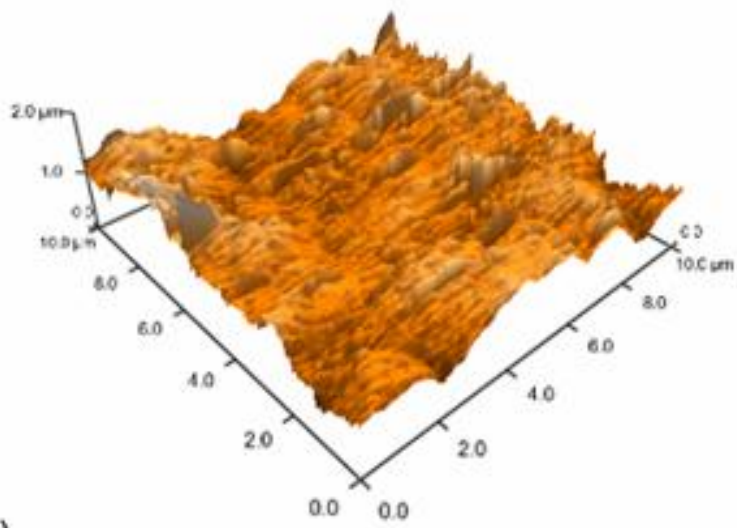

b)

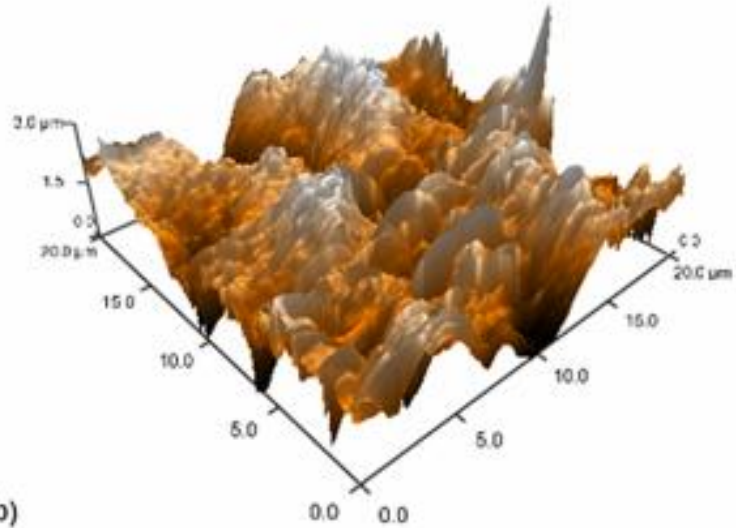

c)

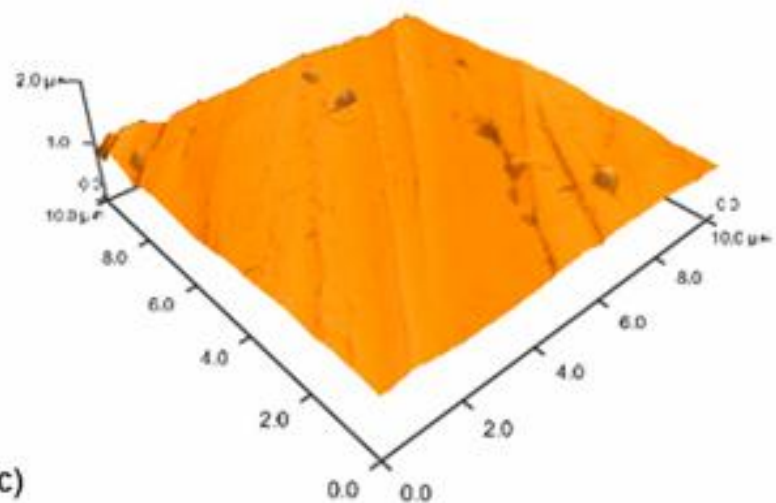

d)

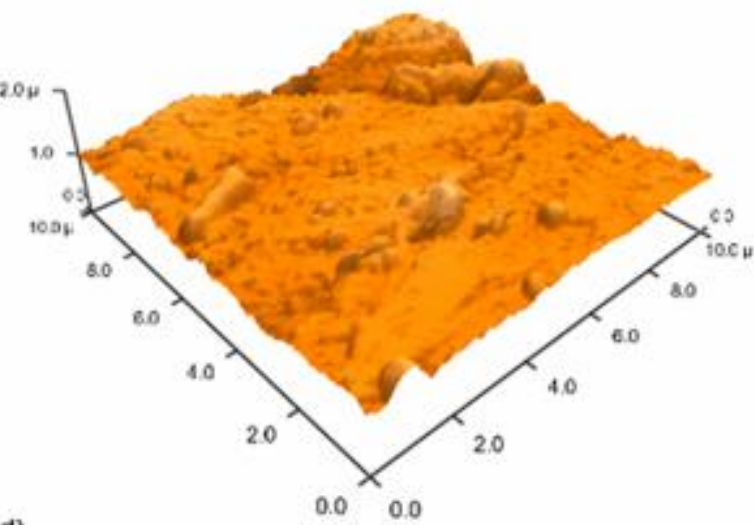

Figure 5 - Atomic force microscopy threedimensional images of mild steel surface in 3 wt. $\% \mathrm{NaCl}$ saturated with $\mathrm{CO}_{2}$ a) without inhibitor at $20^{\circ} \mathrm{C}$, b) without inhibitor at $70^{\circ} \mathrm{C}, \mathrm{c}$ ) containing $70 \mathrm{ppm}_{v}$ TOFA/DETA imidazoline at $20^{\circ} \mathrm{C}$ and d) containing 70 ppm $_{v}$ TOFA/DETA imidazoline at

$70^{\circ} \mathrm{C}$. (Reprinted with permission from [19] Copyright 2013 Elsevier).

\subsection{Corrosion inhibitor performance in the vapor phase - glass cell}

To investigate if the corrosion inhibitor carried by foam matrix can provide sufficient inhibition at the top of the line, sodium C14-16 olefin sulfonate was used as the foaming agent, concentration 20 
vol. \% in DI water. The verification of inhibitive properties of the foam matrix without and with 1000 ppm $_{v}$ of TOFA/DETA imidazoline was performed. The time dependences of metal thickness loss were obtained using the ER probe (Fig. 6) in the vapor phase saturated with $\mathrm{CO}_{2}$ and $\mathrm{H}_{2} \mathrm{O}$ at a total pressure of 1 bar. The temperature of the solution was held constant at $70^{\circ} \mathrm{C}$ while the temperature of the vapor phase was around $60^{\circ} \mathrm{C}$. We have used linear regression to fit metal thickness loss data to a linear relationship and to determine the value of corrosion rate. All the measurements were repeated at least twice and then the representative measurement was shown in the manuscript. Once the baseline corrosion conditions were established in the corrosion cell, the TLC rate of bare steel was around $0.5 \mathrm{~mm} \mathrm{yr}^{-1}$. As can be seen in Fig. 6a, the metal thickness loss increased in the non-inhibited system and kept on increasing with further exposure time even when the ER probe was intermittently taken from the corrosion cell and mounted on the lid of the foaming cell for $60 \mathrm{~s}$ at a time. So, it can be concluded that foaming agent sodium C14-16 olefin sulfonate alone has very poor inhibitive property and does not protect the mild steel from corrosion.
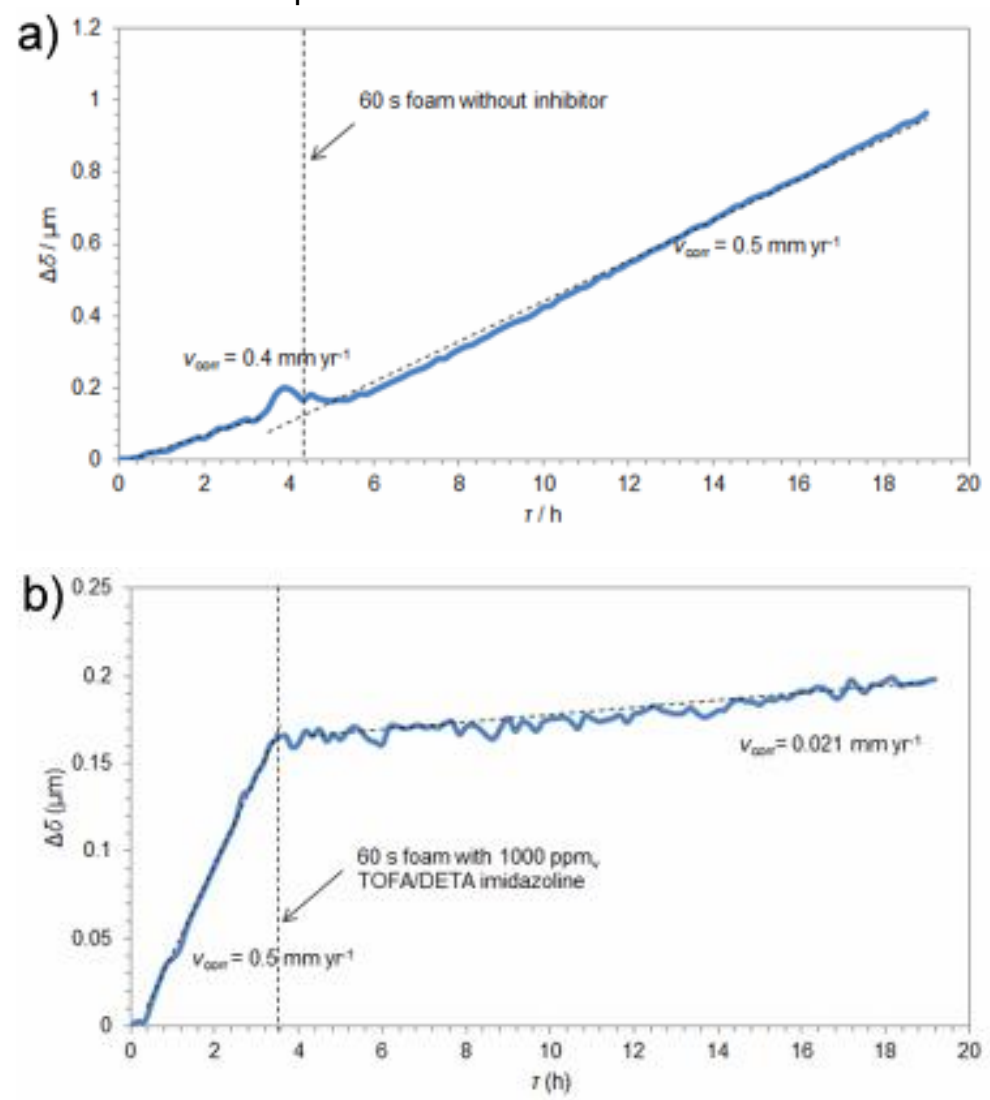

Figure 6 - The time dependences of metal thickness loss for mild steel in vapor phase, contact time $60 \mathrm{~s}$ with foaming agent a) without and b) with 1000 ppm $_{v}$ TOFA/DETA imidazoline (3 wt. \% NaCl solution, at $70^{\circ} \mathrm{C}, \mathrm{pH} 4$ with acetic acid in a concentration of $\left.0.02 \mathrm{~mol} \mathrm{dm}^{-3}\right)$.

The ER probe was then taken from the corrosion cell and flush-mounted on the lid of the foaming cell, containing $1000 \mathrm{ppm}_{\mathrm{v}}$ of TOFA/DETA imidazoline in the aqueous phase at the bottom, for $60 \mathrm{~s}$ at a time, and then returned back to the corrosion cell (Fig. 6b). The corrosion rate remained below $0.1 \mathrm{~mm} \mathrm{yr}^{-1}$, even after $15 \mathrm{~h}$ of exposure. The same results were obtained for lower contact times of $30 \mathrm{~s}, 15 \mathrm{~s}$ and $5 \mathrm{~s}$ (data not shown here). Consequently, it can be considered that the TOFA/DETA imidazoline carried by the foam matrix was effective and significantly decreased the TLC rate.

\subsection{Corrosion inhibitor performance in the vapor phase - flow loop}

In order to raise confidence that the previously obtained results can be applied in the field, the novel TLC mitigation method needed to be evaluated under simulated field conditions. Large scale flow loop studies are better suited for the simulation of corrosive environments and flow conditions (realistic gas temperature, gas flow rate, $\mathrm{CO}_{2}$ partial pressure, and condensation rate) encountered in the field $[27,28]$. In these experiments the foaming agent was injected directly in the middle of the flow stream through a 
nozzle and sprayed on a fine mesh, with uninterrupted gas flow. The method of foam creation provided retention time of the foam matrix coating on the metal surface of approximately 2 min. The time dependence of metal thickness loss for mild steel exposed to vapor phase after the ER probe was contacted by the foam plug without and with corrosion inhibitor is shown in Fig. 7.
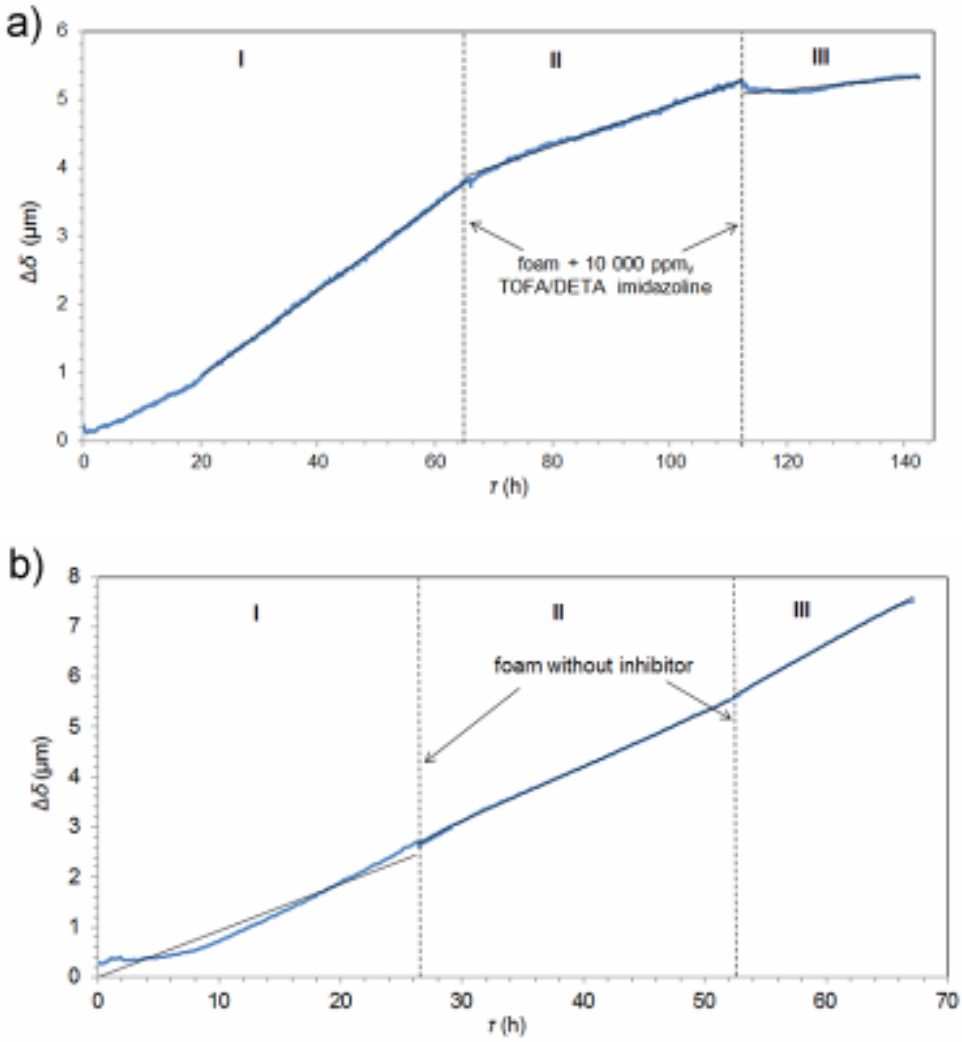

Figure 7 - Time dependence of metal thickness loss for mild steel set in vapor phase after being contacted by the foam plug a) without and b) with 10000 ppm $_{v}$ of TOFA/DETA imidazoline.

The baseline corrosion rate in the vapor phase, measured over an exposure time of $65 \mathrm{~h}$, was in the range from $0.5 \mathrm{~mm} \mathrm{yr}^{-1}$ to $0.8 \mathrm{~mm} \mathrm{yr}^{-1}$ (interval I, Fig. 7). After the ER probe was contacted by a plug of foam without a corrosion inhibitor, the metal thickness loss kept on increasing indicating that the foaming agent alone had no effect on the TLC rate (interval II, $v_{\text {corr }}=0.95 \mathrm{~mm} \mathrm{yr}^{-1}$, Fig. 7a). A plug of foam containing $10000 \mathrm{ppm}_{\mathrm{v}}$ of TOFA/DETA imidazoline was created at the injection port, and the resulting corrosion rate decreased by a factor of two to $0.26 \mathrm{~mm} \mathrm{yr}^{-1}$ (interval II, Fig. 7b). Calculated inhibition efficiency was around $53 \%$ and remained effective for another $50 \mathrm{~h}$. The procedure was then repeated once again with 10 $000 \mathrm{ppm}_{\mathrm{v}}$ of TOFA/DETA imidazoline and the corrosion rate decreased even further to a value of $0.07 \mathrm{~mm} \mathrm{yr}^{-1}$ (interval III, Fig. 7b). The second foam injection was carried out approximately $40 \mathrm{~h}$ after the first injection and approximately $90 \%$ inhibition efficiency was achieved probably due to a better oriented and more completely developed inhibitor film on the metal surface. It seems that successive foam plug injections increase inhibitor placement and provide better corrosion protection.
It was demonstrated that successive injections of foam plugs containing $10000 \mathrm{ppm}_{\mathrm{v}}$ or higher of TOFA/DETA imidazoline inhibitor solution is required to reduce corrosion rates to approximately $90 \%$ inhibition efficiency in the vapor phase. It can be concluded that TOFA/DETA imidazoline carried by the foam matrix forms a thin film on the surface of the ER probe that stops access of the corrosive species to the metal. The obtained results show that the foam matrix can be used to effectively distribute inhibitor liquids to the top of the pipe.

At this point of research, our results indicate that a slug of foam with TOFA/DETA imidazoline, corrosion inhibitor, must be re-applied every $40 \mathrm{~h}$ to $50 \mathrm{~h}$ in order to ensure the ongoing effectiveness of the novel TLC mitigation method.

\section{CONCLUSIONS}

The investigated organic compound TOFA /DETA imidazoline exhibited high inhibition efficiency against mild steel corrosion in 3 wt. \% $\mathrm{NaCl}$ solution saturated with $\mathrm{CO}_{2}$. The protection efficiency increased with increasing inhibitor concentration from $50 \mathrm{ppm}_{\mathrm{v}}$ to $90 \mathrm{ppm}_{\mathrm{v}}$, up to 92 
$\%$. PDS measurements showed that TOFA/DETA imidazoline can be considered a mixed-type corrosion inhibitor with the predominant anodic effect. The addition of TOFA/DETA imidazoline to the liquid phase decreased the $v_{\text {corr }}$ for more than one order of magnitude. A comprehensive study was performed in an innovative glass cell setup which consisted of a foaming cell and a corrosion cell in order to simulate intermittent contact between the foam and the steel surface. The TLC rate of mild steel was effectively reduced by periodic treatment by the foam containing a TOFA/ DETA imidazoline corrosion inhibitor. Repeatable results were obtained for all contact times in the range of $5-60 \mathrm{~s}$, and were persistent for at least 15 hours. A novel TLC mitigation method was also evaluated under simulated field conditions in a large scale multiphase flow loop. The use of a flow loop enabled realistic simulation of the corrosive environments as well as the flow conditions typically encountered in the field. Successive injections of foam plugs containing $10000 \mathrm{ppm}_{\mathrm{v}}$ of TOFA/DETA imidazoline led to approximately $90 \%$ inhibition efficiency and the inhibition effect lasted up to $50 \mathrm{~h}$. The foam matrix is a promising method to deliver a corrosion inhibitor that can control the TLC rate in wet $\mathrm{CO}_{2}$ gas flow.

\section{Acknowledgements}

The authors would like to express their gratitude to ConocoPhillips, USA, and the Ministry of Education, Science and Technological Development, Republic of Serbia (Grant no. III 45019), for the financial support.

\section{REFERENCES}

[1] Q.Y.Liu, L.J.Mao, S.W. Zhou (2014) Effects of chloride content on $\mathrm{CO}_{2}$ corrosion of carbon steel in simulated oil and gas well environments, Corros. Sci., 84, 165-171.

[2] C.De Waard, D.E.Milliams (1975) Carbonic acid corrosion of steel, Corrosion, 31, 177-181.

[3] G.I.Ogundele, W.E.White (1986) Some observations on corrosion of carbon steel in aqueous environments containing carbon dioxide, Corrosion, 42, 71-78.

[4] P.C.Okafor, S.Nesic (2007) Effect of Acetic Acid on $\mathrm{CO}_{2}$ Corrosion of Carbon Steel in Vapor-Water Two-Phase Horizontal Flow, Chem. Eng. Com., 194, 141-157.

[5] F.Vitse, S.Nešić, Y.Gunaltun, D.L. de Torreben, P.Duchet-Suchaux (2003) Mechanistic model for the prediction of top-of-the-line corrosion risk, Corrosion, 59, 1075-1084.

[6] Z.Zhang, D.Hinkson, M.Singer, H.Wang, S.Nešić (2007) A mechanistic model of top-of-the-line corrosion, Corrosion, 63, 1051-1062.
[7] M.Singer, A.Camacho, B.Brown, S. Nešić (2011) Sour Top-of-the-Line Corrosion in the Presence of Acetic Acid, Corrosion, 67, 5-7.

[8] S.Nešić (2007) Key issues related to modelling of internal corrosion of oil and gas pipelines - A review, Corros. Sci., 49, 4308-4338.

[9] D.Hinkson, Z.Zhang, M.Singer, S.Nešić (2010) Chemical Composition and Corrosiveness of the Condensate in Top-of-the-Line Corrosion, Corrosion, 66, 045002-045002-8.

[10] M.Singer, J. Al-Khamis, S.Nešić (2013) Experimental Study of Sour Top-of-the-Line Corrosion Using a Novel Experimental Setup, Corrosion, 69, 624-638.

[11] S.-H.Yoo, Y.-W.Kim, K.Chung, S.-Y.Baik, J.-S.Kim (2012) Synthesis and corrosion inhibition behavior of imidazoline derivatives based on vegetable oil, Corros. Sci., 59, 42-54.

[12] G. Žerjav, I. Milošev (2015) Corrosion protection of brasses and zinc in simulated urban rain. Part II. The combination of inhibitors benzotriazole and 2mercaptobenzimidazole with stearic acid, Mater. Corros., 67(1), 92-103.

[13] V.S.Reznik, V.D.Akamsin, Y.P.Khodyrev, R.M. Galiakberov, Y.Y.Efremov, L. Tiwari (2008) Mercaptopyrimidines as inhibitors of carbon dioxide corrosion of iron, Corros. Sci., 50, 392-403.

[14] M.Finšgar, I.Milošev (2010) Inhibition of copper corrosion by 1, 2, 3-benzotriazole: a review, Corros. Sci., 52, 2737-2749.

[15] M.Finšgar, J.Kovač, I.Milošev (2010) Surface analysis of 1-hydroxybenzotriazole and benzotriazole adsorbed on $\mathrm{Cu}$ by X-ray photoelectron spectroscopy, J. Electrochem. Soc., 157, C52-C60.

[16] M.Finšgar, J.Jackson (2014) Application of corrosion inhibitors for steels in acidic media for the oil and gas industry: A review, Corros. Sci., 86, 17-41.

[17] I.Jevremovic, A.Debeljkovic, M.Singer, M.Achour, S.Nesic, V.Miskovic-Stankovic (2012) The mixture of dicyclohexilamine and oleylamine as corrosion inhibitor for mild steel in $\mathrm{NaCl}$ solution saturated with $\mathrm{CO}_{2}$ under both continual immersion and top of the line corrosion, J. Serb. Chem. Soc., 77, 10471061.

[18] I. Jevremovic, M.Singer, M. Achour, D.Blumer, T.Baugh, V. Miskovic-Stankovic, S. Nesic (2013) A Novel Method to Mitigate the Top-of-the-Line Corrosion in Wet Gas Pipelines by Corrosion Inhibitor within a Foam Matrix, Corrosion, 69, 186192.

[19] I.Jevremovic, M.Singer, S.Nesic, V.MiskovicStankovic (2013) Inhibition properties of selfassembled corrosion inhibitor talloil diethylenetriamine imidazoline for mild steel corrosion in chloride solution saturated with carbon dioxide, Corros. Sci., 77, 265-272.

[20] G. Zhang, C.Chen, M. Lu, C.Chai, Y.Wu (2007) Evaluation of inhibition efficiency of an imidazoline derivative in $\mathrm{CO}_{2}$-containing aqueous solution, Mater. Chem. Phys., 105, 331-340.

[21] J.Cruz, R.Martínez, J.Genesca, E.García-Ochoa (2004) Experimental and theoretical study of 1-(2- 
ethylamino)-2-methylimidazoline as an inhibitor of carbon steel corrosion in acid media, J. Electroanal. Chem., 566, 111-121.

[22] I.Jevremović, M.Singer, M.Achour, V.MiškovićStanković, S.Nešić (2015) Evaluation of a Novel Top-of-the-Line Corrosion (TLC) Mitigation Method in a Large-Scale Flow Loop, Corrosion, 71, 389397.

[23] I.Jevremovic, M.Singer, S.Nesic, V.MiskovicStankovic (2015) Electrochemistry of carbon dioxide corrosion mitigation using tall oil diethylenetriamine imidazoline as corrosion inhibitor for mild steel, Mater. Corros., DOI: 10.1002/maco.201508629.

[24] S.Nesic, B.F.M.Pots, J.Postlethwaite, N.Thevenot (1995) Superposition of diffusion and chemical reaction controlled limiting currents--application to $\mathrm{CO}_{2}$ corrosion, J. Corros. Sci. Eng., 1, 1-14.
[25] S.Nesic, J.Postlethwaite, S.Olsen (1996) An Electrochemical Model for Prediction of Corrosion of Mild Steel in Aqueous Carbon Dioxide Solutions, Corrosion, 52, 280-294.

[26] M.Knag, K.Bilkova, E.Gulbrandsen, P.Carlsen, J.Sjöblom (2006) Langmuir-Blodgett films of dococyltriethylammonium bromide and octadecanol on iron. Deposition and corrosion inhibitor performance in $\mathrm{CO}_{2}$ containing brine, Corros. Sci., 48, 25922613.

[27] S.Nesic, L.Lunde (1994) Carbon dioxide corrosion of carbon steel in two-phase flow, Corrosion, 50, 717-727.

[28] C.G.Kirkbridge (1933) Heat Transmission by Condensing Pure and Mixed Substances on Horizontal Tubes, Ind. Eng. Chem., 25, 1324-1331.

\section{IZVOD}

\section{RAZVIJANJE EFIKASNE METODE ZAŠTITE CEVOVOVODA OD UNUTRAŠNJE KOROZIJE U PRISUSTVU $\mathrm{CO}_{2}$}

U ovom radu je dat pregled dosadašnjih rezultata razvijanja efikasne metode zaštite cevovoda od unutrašnje korozije u prisustvu $\mathrm{CO}_{2}$. Efikasnost organskog inhibitora, imidazolinskog derivata smeše viših masnih kiselina i dietilentriamina, TOFA/DETA imidazolina za zaštitu niskougljeničnog čelika API X65 od korozije u 3 mas. \% $\mathrm{NaCl}$ rastvoru zasićenom sa $\mathrm{CO}_{2}$ ispitivan je primenom metode linearne polarizacione otpornosti, metode polarizacione krive, metode određivanja gubitka mase na osnovu električne otpornosti, metode mikroskopije atomskih sila. Nova metoda zaštite od korozije u uslovima kondenzacije je ispitivana u staklenoj ćeliji kao i u sistemu sa višefaznim tokom fluida, posebno konstruisanom za ispitivanje uticaja operativnih parametara na koroziju čelika u uslovima kondenzacije. Na osnovu dobijenih rezultata merenja vršenih u tečnoj fazi potvrđeno je da je inhibitor TOFA/DETA imidazolin dobar i efikasan inhibitor za koroziju niskougljeničnog čelika u rastvoru 3 mas. \% NaCl zasićenom sa $\mathrm{CO}_{2}$ uz izmerenu vrednost efikasnosti inhibicije preko $92 \%$. Pena sa TOFA/DETA imidazolinom efikasno smanjuje brzinu korozije čelika u gasovitoj fazi uz efikasnost inhibicije od oko $90 \%$ i vreme trajanja izvedene zaštite od korozije do $50 \mathrm{~h}$.

Ključne reči: niskougljenični čelik, $\mathrm{CO}_{2}$ korozija; inhibitori korozije; metode linearne polarizacione otpornosti; metoda polarizacione krive; mikroskopija atomskih sila; sistem za merenje brzine korozije u uslovima kondenzacije.

\section{Pregledni rad}

Rad primljen: 13. 02. 2016.

Rad prihvacen: 17. 03. 2016.

Rad je dostupan na sajtu: www.idk.org.rs/casopis 